\title{
Guerilla Marketing of Fresh Organic Agricultural Products
}

\author{
Adjnu Damar-Ladkoo \\ Faculty of Law \& Management, University of Mauritius, Réduit, Mauritius \\ Email:a.ladkoo@uom.ac.mu
}

Received 29 February 2016; accepted 23 April 2016; published 26 April 2016

Copyright (C) 2016 by author and Scientific Research Publishing Inc.

This work is licensed under the Creative Commons Attribution International License (CC BY). http://creativecommons.org/licenses/by/4.0/

(c) (i) Open Access

\begin{abstract}
The aim of this exploratory study was to gather understandings about guerilla marketing of fresh organic agricultural products from the perspectives of: farmers, marketers and customers in Mauritius, considered being one of the thriving islands of the Indian Ocean and a success story of the African continent. Gathering fruitful insights about the penetration of fresh organic agricultural products via guerilla marketing - a novel, unconventional approach with its associated innovative, imaginative and surprise elements-in this lustrous market was interesting. Responses obtained from the supply and demand point of views, revealed that many were reluctant to consume fresh organic agricultural products but, promoting the latter via guerilla marketing could be beneficial. However, traditional marketing approaches were still much appreciated and thus, setting the right key performance indicators to measure success of the marketing of fresh organic agricultural products via guerilla marketing as compared to traditional marketing methods was vital.
\end{abstract}

\section{Keywords}

Agricultural, Guerilla, Marketing, Mauritius, Organic, Products

\section{Introduction}

When food products, such as most fresh vegetables, are highly perishable, they are not traded internationally on a large scale [1] and modern storage facilities have yet to convince consumers that stored frozen agricultural products have the same freshness, nutrient loads and value as fresh ones. Thus, marketing of fresh agricultural products quickly has become imperative. Furthermore, rising rates of diabetes, coronary diseases and other foodassociated health problems have impelled consumers to think twice before buying food and the tendency is towards genuine fresh agricultural products without chemical products like pesticides. While agriculture serves as the livelihood for billions of people around the globe, it often conflicts with its own long-term viability [2] and 
so, people are becoming conscious about sustainable development. Thus, there is visible movement towards the consumption of fresh organic agricultural products. Organic agriculture considers the medium- and long-term effect of agricultural interventions on the agro-ecosystem [3]. In many countries like Mauritius, South Africa, United Kingdom and Singapore, retail outlets have dedicated several shelves spaces for fresh organic agricultural products. As per [4] a significant number of consumers have expressed a willingness to pay a premium for environmentally friendly (e.g., organic) and locally produced products. This implies that the marketing of such products should be done rapidly due to their perishable nature. As pointed by [5] the perishable nature of agricultural products resulted in urgency in the marketing of these products. This has become a real challenge whether for farmers doing direct marketing or for those choosing indirect marketing via wholesalers, retailers or agents. As such, tactful marketing strategies should be adopted so as to ease the flow of fresh organic agricultural products towards consumers. Amongst the several existing marketing strategies is that of guerilla marketing. This new study will focus on the perspectives of several key stakeholders regarding marketing of fresh organic agricultural products and guerilla marketing.

The objectives of the study have been set as follows:

- To know the current marketing status of fresh organic agricultural products on the Mauritian market.

- To evaluate the perception and effect of guerilla marketing on the Mauritian market.

- To determine how marketing of fresh organic agricultural products in Mauritius can be successful via guerilla marketing.

\section{Guerilla Marketing and Its Application in Agriculture}

In recent years, many companies, looking for ways of getting out of clutter of traditional marketing implementations, tend to apply guerrilla marketing which is a different way of marketing communication [6]. Many authors have attempted to frame the essence of guerilla marketing within certain terms and yet, all these definitions carry some similar elements which are: 1) the tactical approach, 2) the surprise effect, 3) the use of unconventional methods and ideas, and 4) the use of a low budget. [7] states that a guerilla marketing strategy takes the customer by surprise and makes an indelible impression. [8] says that guerilla marketing campaign presents brands in a shocking, funny, unique, clever, or creative image that make people cannot stop talking about it. [9] adds that a guerilla marketing tactic is conducted very much like the military tactic from which it takes its name, operating on a small scale in terms of resources and relying more on the tactical efforts, which here takes a more creative spin. Consequently, guerilla marketing can be described as a planned marketing promotional strategy using original yet, strange techniques to astonish and attract customers. It is visible on the market that fresh organic agricultural products are expensive compared to their conventional equivalents and it is thus, vital to choose a marketing strategy that will not only grasp the attention of consumers but, which is affordable as well. Neven et al. (2009 cited in [10]) found that, in the case of fresh fruit and vegetables, minimum levels of physical, financial, human and organisational capital endowments are necessary for producers to be able to penetrate existing supermarket channels. According to [3] certified organic products are generally more expensive than their conventional counterparts (for which prices have been decreasing) for a number of reasons: 1) Organic food supply is limited as compared to demand, 2) Production costs for organic foods are typically higher because of greater labour inputs per unit of output and because greater diversity of enterprises means economies of scale cannot be achieved, 3) Post-harvest handling of relatively small quantities of organic foods results in higher costs because of the mandatory segregation of organic and conventional produce, especially for processing and transportation, and 4) Marketing and the distribution chain for organic products is relatively inefficient and costs are higher because of relatively small volumes. Consequently, this research aims to clarify the use of guerilla marketing on fresh organic agricultural products so as to revitalize it. This paper will contribute towards both sustainable development and the marketing of fresh agricultural products.

\subsection{Effects and Instruments of Guerilla Marketing}

[11] states that until now no uniform categorization of guerilla marketing instruments have prevailed but, the most important ones are structured in the three categories "infection guerrilla marketing", "surprise guerrilla marketing" and "ambush marketing" while "Low budget guerrilla marketing" is a special case that can be subsumed to all other categories. [12] states that there are 3 major effects of guerilla marketing: 1) surprise effect, 2) diffusion effect, and 3) low cost effect and adds that marketers utilize the surprise effect by making effective 
usage of humor, absurdity and shocking in the ad message which awaken people’s attention by implementing ad campaigns at different unusual locations with unfamiliar means of media and promotion techniques. For Belch \& Belch (2004 cited in [12]), a surprised person stops his previous activity and switches his attention on the surprising event. In order to stimulate general public to share and diffuse the message, the ad should trigger the emotion surprise, since it motivates people to share their experiences [12]. The low cost effect is achieved when surprised people share their experiences to others and eventually it takes a snow-balling approach. Moreover, when marketers are able to implement guerilla marketing at crowded placed, they can easily target thousands of customers at a time. [13] categorised the guerrilla marketing weapons as follows: 1) Out of Home Weaponambient marketing, guerilla sensation and ambush marketing, 2) New Media Weapons—viral marketing and guerilla mobile, and 3) Low Budget Weapons-clever ideas for small and medium enterprises.

[14] describe ambient marketing the placement of advertising in unusual and unexpected places (location) often with unconventional methods (execution) and being [the] first or only ad execution to do so (temporal). For [15] sensation marketing is aiming towards surprising pedestrians in public places by different activities that surpass the familiarity levels. Ambush marketing is the practice where a company tries to capitalize on the publicity surrounding particular massive event, depriving public attention from a competitor and drawing attention towards itself [16]. For [17] viral marketing communication concerns the informal, peer-to-peer electronic exchange of information about an identifiable product or service. With the rise in technology and the ever-growing use of social networks like Facebook, Twitter, Whats App and others, consumers can communicate via several novel digital mediums within seconds. [18] state that traditional advertising efforts can be quite costly and many entrepreneurs simply do not have a lot of money to spend. Rather than buying expensive advertisements to appear in or run on traditional media outlets, entrepreneurs who rely on guerilla marketing strategies focus on coming up with creative, affordable ways to promote their businesses [19].

The above guerilla marketing instruments have been used on many products but, visibly much less on fresh organic agricultural products. This research would contribute in an original manner so as to discover the perceptions of various stakeholders of fresh organic agricultural products about the instruments and effects of guerilla marketing. However, all marketing strategies need to be insightfully implemented so as not harm the society and to meet the expectations of the stakeholders.

\subsection{Tactics and Ethics of Guerilla Marketing}

There are seven tactical rules of competition via guerilla marketing according to [20], which are as follows: 1) concentrating the company's resources (time, place and topic) to achieve temporary superiority, 2) sell the ideology along with the product, not the product alone, 3) identify established patterns, analyze them and overcome these patterns, 4) search for collaborations between two or more influences that, together, create a stronger influence, 5) try to outsmart any perception filters established in the target group, 6) try to find detours offering alternatives, and 7) a company should be flexible and agile instead of building strongholds.

Yet, marketers have to be cautious as according to [6] guerilla advertising even carries some dangers like ads placed in the middle of the road or on public buses, cabs, or private vehicles may cause traffic accidents as it distracts the drivers, their content and design may carry the risk of jeopardizing the traffic. [6] also point that guerilla advertisement sometimes may have a negative effect on children like behavior imitations while trespassing on private or public property without getting permission is the other ethical problem of guerrilla advertising.

Based on the above, marketers of fresh organic agricultural products have to wisely plan all guerilla marketing activities so as to genuinely reap fruitful outcomes.

\subsection{Model}

Several are the models that have been developed about the hierarchy of effects for consumers and the most famous one, regrouping major elements from all the different models is the AIDA Model. The developer of the AIDA Model was St. Elmo Lewis in 1900 [21]. As per Strong (1925 cited in [22]) AIDA is in fact an acronym for attention, interest, desire and action and describes a cognitive journey of a consumer that travels through four main stages and this model can be approached as a tool to encourage action by stimulating the purchase of a certain product or service. As such, it would be original to understand at which stage of this model could guerilla marketing impact more while promoting fresh organic agricultural products. It should however be pointed out 
that other controlled factors like label, price, layout/ presentation, salesperson's approach and uncontrolled factors like colour of the product, climate (example winter or summer) and so on can alter the effects of guerilla marketing.

\section{Methodology}

The research was conducted in Mauritius, a country where people are being encouraged to consume fresh agricultural products for their own welfares and the benefits of rising fresh organic agricultural entrepreneurs. The government of Mauritius has been pushing the agriculture sector to boost food production to increase the country's self-sufficiency and a reasonable level of success has already been achieved, with farmers producing almost 100 per cent of the country's needs in fresh vegetables [23]. Yet, according to [24] it relatively difficult to cut down cost of production to such extent as to compete with big producer countries which have a better comparative advantage and trade liberalization within the Southern African Development Community (SADC), Common Market for Eastern and Southern Africa (COMESA) and the Sanitary and Phytosanitary Agreement of the World Trade Organisation (WTO) will increasingly open markets and encourage new entrants. Thus, the author believes that the numerous advantages provided by guerilla marketing, can alleviate this situation; at least on the marketing side.

The methodology embraced 3 phases: phase 1) Marketers of 5 major wholesale and retail outlets were interviewed with open-ended questions to gauge their perceptions about the usage of guerilla marketing for fresh organic agricultural products, phase 2) a detailed consumer survey was done in which 300 consumers (a quota of 30 consumers per 10 retail/wholesale outlets in Mauritius) were questioned about the consumption of fresh organic products, their know-how about guerilla marketing and its potential impacts on them and, phase 3) 5 farmers involved in direct marketing of fresh organic agricultural products were interviewed through open-ended questions. $100 \%$ response rate was obtained and the respondents' desire to stay anonymous was respected. The above research methodology was found to be appropriate as it gave a holistic view about the use of guerilla marketing for promoting fresh organic agricultural products. The following research questions were addressed in this study:

- What is the current marketing status of fresh organic agricultural products on the Mauritian market?

- How do different stakeholders of fresh organic agricultural products perceive guerilla marketing on the Mauritian market?

- Can marketing of fresh organic agricultural products in Mauritius can be successful via guerilla marketing activities?

- At which stage of the consumer buying process can guerilla marketing create a positive impact on the purchase decision?

\section{Findings and Discussion}

The findings have been elaborated in a way so as to gain information from the supply point of view (from farmers and retail/whole outlets) and then from the demand point of view (consumers).

\subsection{Retail/Wholesale Outlets' and Farmers' Responses about Fresh Organic Products and Guerrilla Marketing}

Organic products are renowned for their properties of being free of chemicals, pesticides and preservatives and the latter is one of the most prominent reasons why $100 \%$ retail outlets marketed such products. In fact, marketing food with $0 \%$ pesticide, fertilizers or preservatives meant that the retail outlets are engaging themselves in corporate social responsibility since they are encouraging their customers to buy healthier products. However, the unwillingness of the $40 \%$ farmers to market such products could be explained by the fact that for them, not using fertilizers, pesticides and chemicals implied more rigorous farming and post-farming practices and processes so as to prevent their crops from being infected by pests and diseases (Figure 1).

Though $60 \%$ farmers and $100 \%$ retail outlets market fresh organic agricultural products, it was nevertheless surprising to note that out of their total vegetable quota meant for sales, only a certain percentage was attributed to fresh organic agricultural products. This reluctance of having a full fledge marketing of fresh organic agricultural products could be explained by the fact that demand on the side of consumers is as well not full fledge. The 
$\square$ Yes $\square$ No

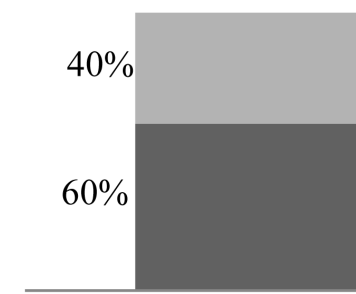

Farmers

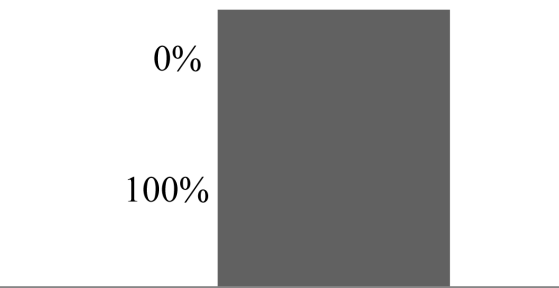

Retail outlets

Figure 1. Do you market fresh organic agricultural products?

rigid agricultural practices connected to growth of organic foods associates reveals one major characteristic of the latter being high price. This can be an impediment for consumers while buying such products. Hence, farmers and marketers have to still cater for the needs of those people who do not desire fresh organic agricultural products (Figure 2).

The responses clearly demonstrate that both producers and marketers are keen to sell fresh agricultural organic products; even if they stated in their interview that it is much more difficult to market such products. This is the reason why only a percentage of either $50 \%$ or $25 \%$ fresh organic agricultural products are being sold and not $100 \%$. The latter are nevertheless aiming at educating their customers regarding consumption of such products (Figure 3). According to [25] promotional efforts will have to focus on "educating" consumers on the relationship between organic produce, health and the environment. Interestingly, even if it is much less done on the farmers' side, educating the population about the consumption of fresh organic agricultural products is on the way. Yet, successful results might be seen if interesting promotional methods are used and one of them is guerilla marketing. As pointed earlier, guerilla marketing instruments have been used on many products but, visibly much less on fresh organic agricultural products. Thus, the respondents were questioned whether firstly they were aware about guerilla marketing and those who knew about it were further queried about the activities that they were undertaking for implementing guerilla marketing.

It was motivating to note that marketers of retail/wholesale outlets were aware about guerilla marketing while it was unfortunately, the contrary for farmers. During the interview, it was highlighted by the $60 \%$ farmers who were marketing fresh organic agricultural products that they had many difficulties in convincing people to buy such products (Figure 4). As such, [25] rightly pointed out that Government policies related to the provision of market information to marketing decision-makers and consumers could also improve the performance of the organic marketing system. The 5 stages of consumer buying process starts with problem or need identification, information search, evaluation of alternatives, purchase and post purchase behaviour. It can therefore, be said that for customers to consider fresh organic agricultural products in their purchase and to be able to move to the subsequent stages, educating customers with the right motivating information is important for successful marketing of the latter. Not all, but guerilla marketing activities can surprise people with the aim of positively impact on the purchase behaviour. It was thus, interesting to know how guerilla marketing could impact on the sale of fresh organic agricultural products.

[12] states that there are 3 major effects of guerilla marketing: 1) surprise effect, 2) diffusion effect, and 3) low cost effect. Respondents who were using guerilla marketing totally agreed on the above 3 effects, but, emphasized more on guerilla marketing activities' ability to achieve the $1^{\text {st }}$ and $2^{\text {nd }}$ effects. They argued that the low cost effect might come much later when people are satisfied with the products, become loyal customers and encourage others to consume such products. The retail/wholesale outlets' marketers pointed that guerilla marketing can encourage consumption of fresh organic agricultural products and consequently, many other stakeholders namely farmers, would benefit from it. They stressed that low cost can only then be achieved, if demand and production increases. The marketers also stated that guerilla marketing activities can certainly get the attention of consumers to finally boost their purchase action as per the AIDA Model which as per [26] can be explained as follows: once the marketer has the attention of the consumer, they must craft their interest through product 


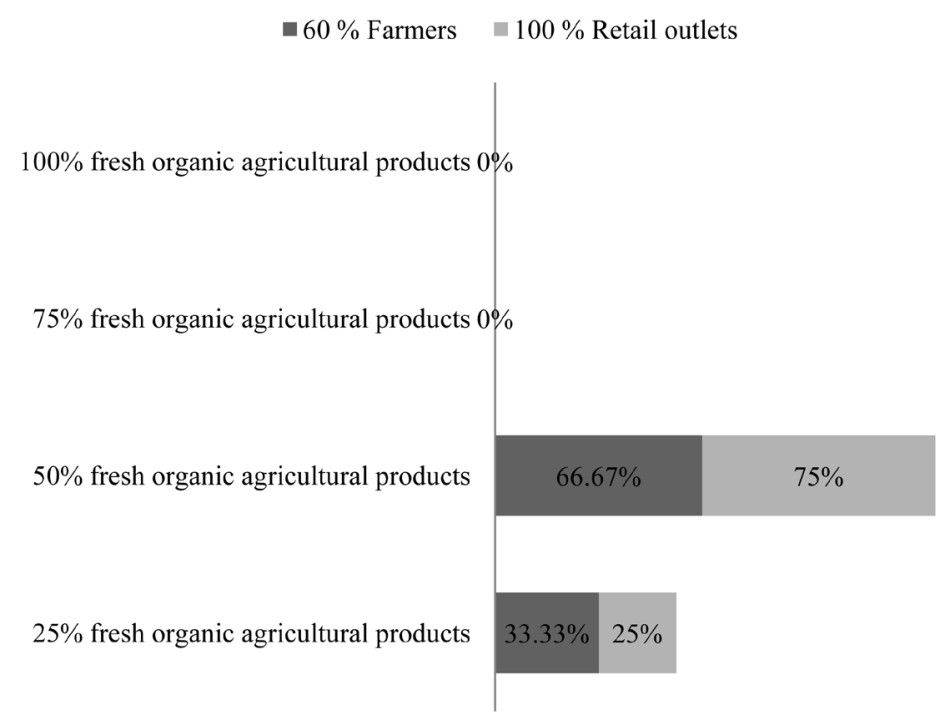

Figure 2. What percentage of the fresh organic agricultural product do you market?

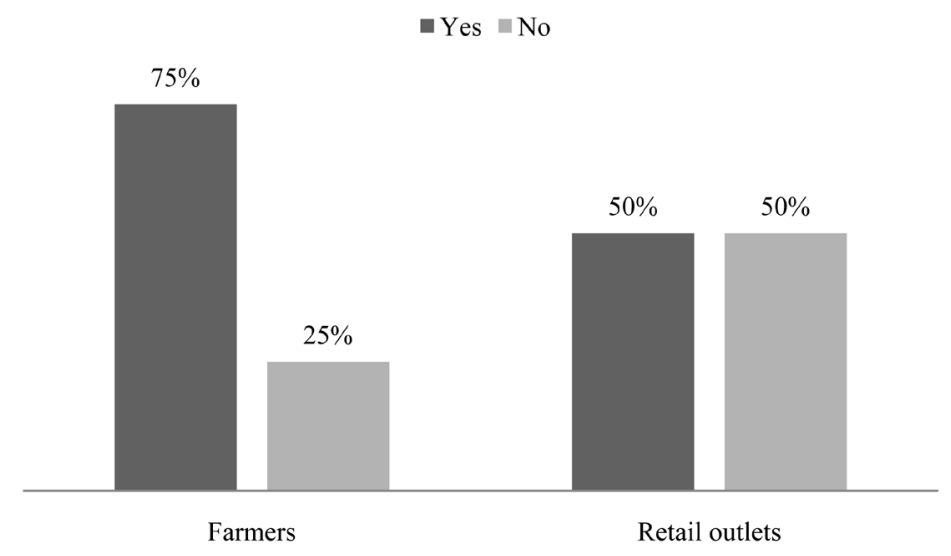

Figure 3. Do you educate your customers regarding consumption of the fresh organic agricultural product?

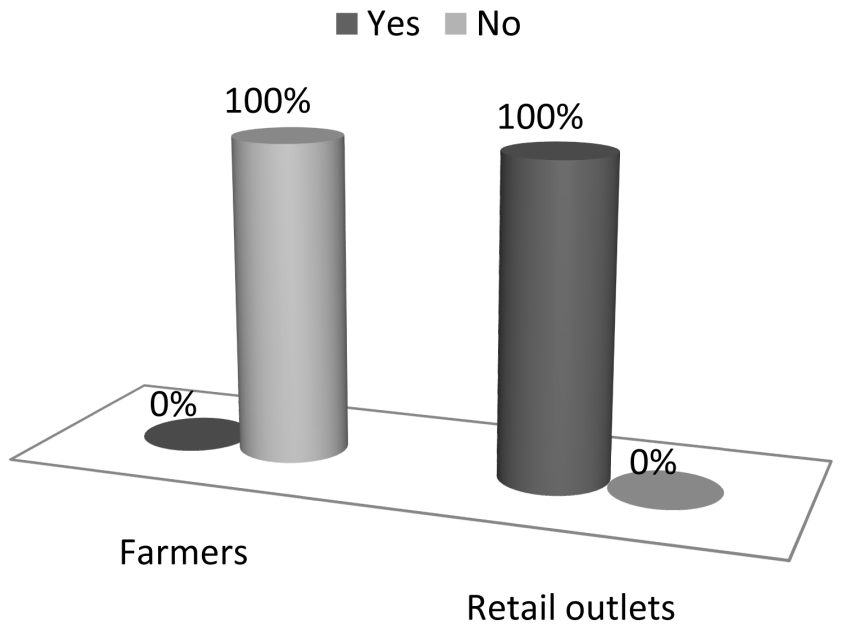

Figure 4. Do you know what guerilla marketing is? 
demonstrations, information and ads. Companies must then build desire by focusing on creating a want for their specific brand, and lastly, consumer action through promotions, discounts and calling out of features or benefits.

\subsection{Customers' Responses about Fresh Organic Products and Guerrilla Marketing}

Even if farmers and retail/wholesale outlets are marketing fresh organic agricultural products, many consumers are still reluctant to buy the latter. A summary of answers for open ended questions to customers revealed that there are several impediments to the purchase of fresh organic agricultural products (Figure 5 and Figure 6) but, the most striking one remains the lack of knowledge about such products. This means that most probably the efforts done by the suppliers to educate consumers are not sufficient. Just like educating a child so as to become a top professional later, marketing of new products are similar. Groundwork regarding educating consumers about the consumption of fresh organic agricultural products should start from children. Both public and private institutions might collaborate to enhance knowledge about consumption of fresh organic agricultural product. But, cost might be an issue. As such, as mentioned earlier, guerilla marketing requires low budget and can be applied to businesses. Surprise effects supplemented by humor and fun can work more easily on children and eventually, they can convince their parents to purchase the above products.

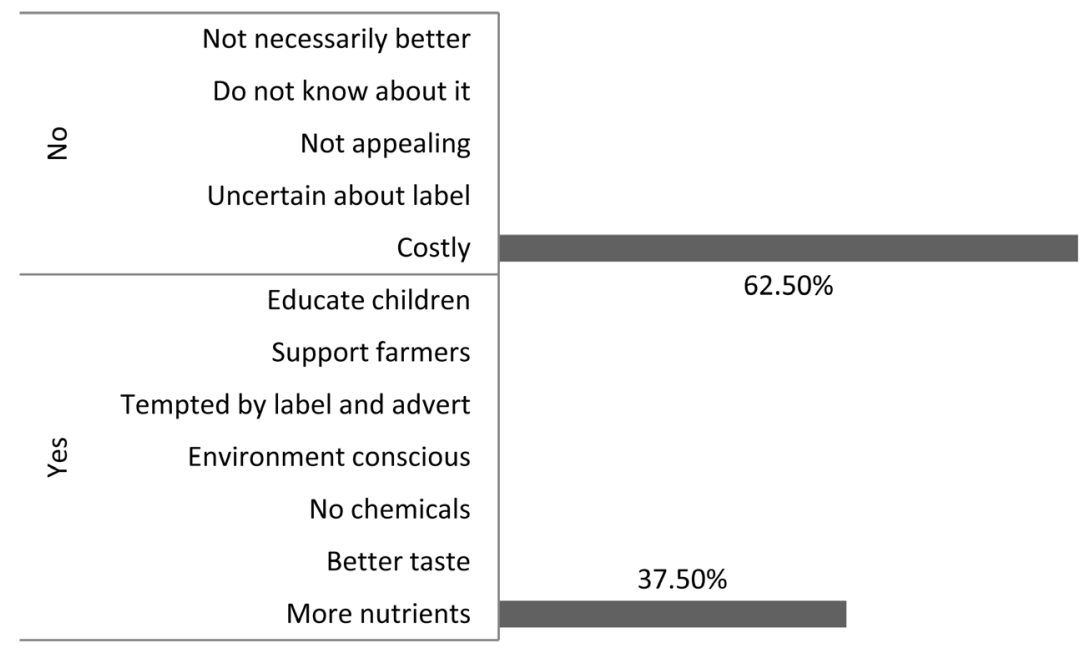

Figure 5. Do you consume fresh organic agricultural products? Why?

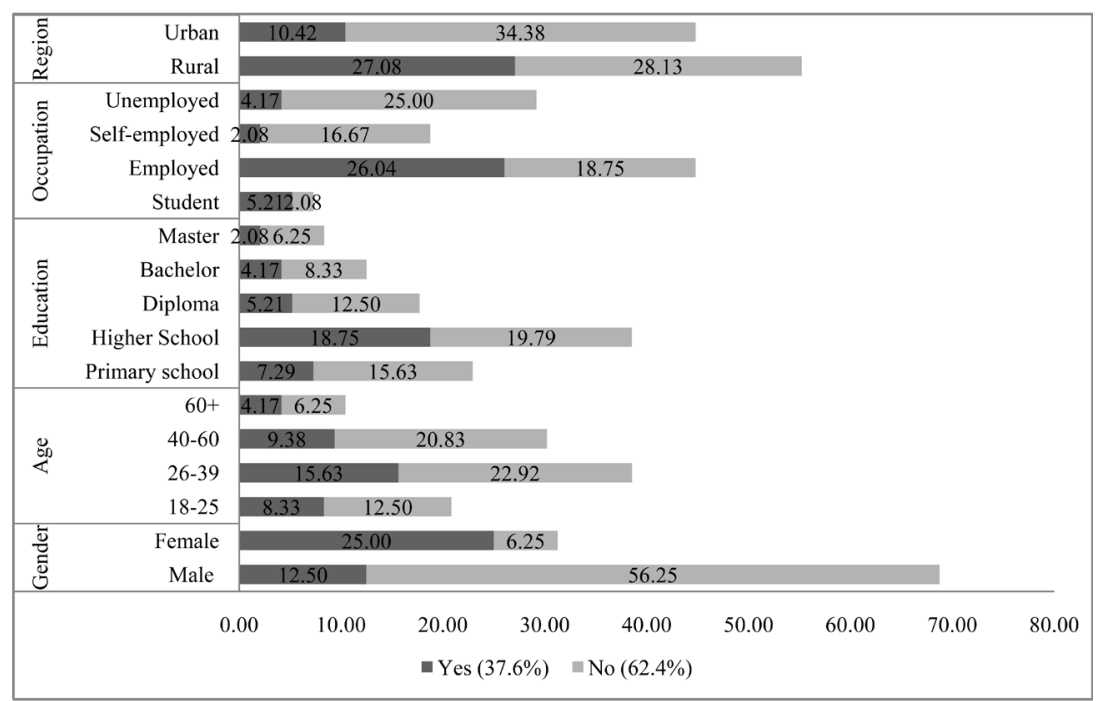

Figure 6. Relating demographic profile of respondents to the question "do you consume fresh organic agricultural products”? 
Furthermore, the above results were enhanced by relating the demographic profile of the respondents to the consumption of fresh organic agricultural products. Most of the respondents were: 1) males, 2) aged 26 - 39 years, 3) education level till higher school, 4) employed, and 5) from rural areas. These profiles were not planned but, coincidental since a quota and convenience sampling was used. Future studies can focus specifically on a demographic profile. All profile categories, except students and females, answered with a 'no' when queried whether they had consumed fresh organic agricultural products. Without being discriminatory and by considering the Mauritian culture, it might be assumed that since mostly women manage kitchens, they might be more open to experiencing new product categories-that is fresh organic agricultural products on the market. As for the students, it might be assumed that the new generation might be more open to tasting new products. Yet, what is more alarming was the "no" obtained from most respondents regarding consumption of fresh organic agricultural products. This confirms that it has become imperative for marketers and producers to correctly educate and market the population about fresh organic agricultural products.

With the power of guerilla marketing, the above can be done but, the study also revealed that $71.87 \%$ consumers never witnessed a guerilla marketing activity while only $28.13 \%$ did. It is vital to point out that the researcher gave a definition of guerrilla marketing to all its respondents so as to ensure that they are aware about it. Those who witnessed a guerilla marketing activity were asked about their reactions as well as preference of such marketing activity over traditional ones and below are their responses:

The study revealed much about the effects of guerilla marketing activities; whereby most of the respondents wanted to know more about the product and brand and also desired to purchase it. As such, this was a positive sign for farmers and marketers who can opt for guerilla marketing activities so as to increase their sales figures (Figure 7). Nevertheless, the study also revealed that consumers were still attached to the traditional marketing activities, except in the stage of purchase where respondents preferred guerilla marketing activities. It was interesting to note that some people did not bother much about guerilla marketing since they were mostly still attached to traditional marketing activity while people who purchased a product due to a guerilla marketing activity were less connected to traditional marketing activity. The challenge of marketers has always been to satisfy the needs and wants of clients in terms of price, packaging, product quality and features, service level amongst others and it was thought-provoking to note from the study that even marketing activities had a role in converting potential customers to genuine consumers of a product. According to [27] the barriers to increase the convert rate can be costs and inconsistencies between marketing and clients' needs. As such, guerilla marketing can truly help because it is less costly than traditional marketing activities.

Even if the study revealed that more than $50 \%$ of the respondents do not consume fresh organic agricultural products, it was important to understand how guerilla marketing could persuade them to buy such products. Thus, the open-ended question set to shed light on the above was as follows: If farmers and marketers use guerilla marketing, an unconventional marketing method, to sell their products, what can it be so as to convince you to buy fresh organic agricultural products? Below is a summary of common responses:

- Live cooking of fresh organic agricultural products at unexpected places.

- Huge mascots representing fresh organic agricultural products.

- Prefer Traditional Marketing Activity $\quad$ Prefer Guerilla Marketing Activity

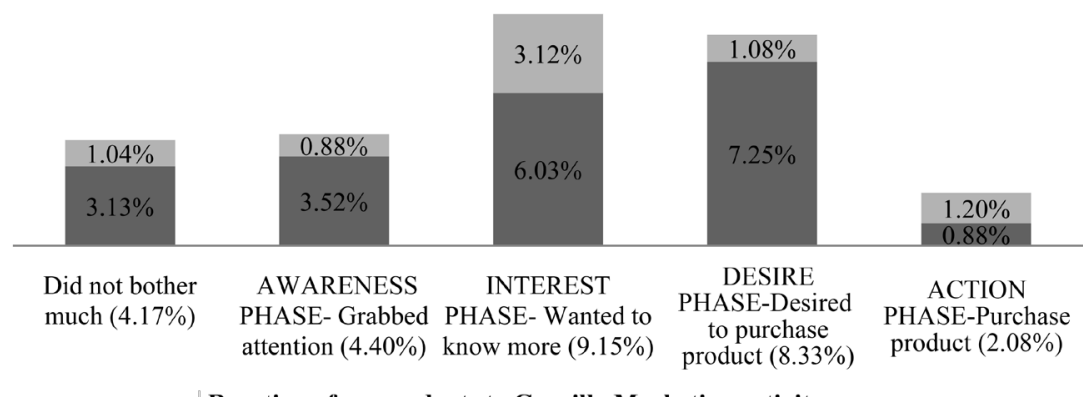

Reaction of respondents to Guerilla Marketing activity

Figure 7. Reaction to guerilla marketing activity and preference of traditional or guerilla marketing activity. 
- Huge flying balloons representing fresh organic agricultural products.

- Digital personal selling of fresh organic agricultural products.

- Obtaining unexpected discount coupons for buying fresh organic agricultural products.

- Bus stops and shopping mall spaces having huge exhibits of fresh organic agricultural products.

\section{Conclusions}

Both guerilla marketing and fresh organic agricultural products are new on the Mauritian market and it will take time for them to get appreciated. The study revealed that the population has to be educated regarding consumption of fresh organic agricultural products and also showed that guerilla marketing does contribute to moving the customers from the awareness phase to the interest and purchase phase. Thus, it would certainly be interesting to combine both by promoting fresh organic agricultural products via guerrilla marketing. One major way, fresh organic agricultural product demarcates itself from regular agricultural products is visibly in terms of quality. So, while promoting fresh organic agricultural products via guerilla marketing, emphasis can be laid on the element of quality as well because as per [28] a favorable perception of quality can enable a firm to charge a premium for its products or services, thus creating gross margins that can be reinvested in brand equity. Moreover, for the idea of doing guerilla marketing to progress according to [29] the employees of wholesale and retail shops should be motivated by heavily involving them in the implementation.

Yet, marketers have to be cautious and should set specific key performance indicators so as to properly judge the success of guerilla marketing compared to traditional marketing because many people still appreciate traditional marketing activities. Amongst some of the key performance indicators can be: 1) customer satisfaction (does the guerilla marketing activity matches the needs and wants for all types of customers?), 2) brand image upliftment (does the guerilla marketing activity make all customers develop positive feelings about the product and brand?), 3) communication of uniqueness of product and brand (does the guerilla marketing activity create competitive differences?), and 4) customer retention and loyalty (does the guerilla marketing activity attract customers, who stay?). As rightly pointed out by [30] customer contribution, especially sustained and increasing customer contribution, is the key to business benefits. Direct marketing of fresh organic agricultural products done by farmers and future new entrepreneurs should continue but, the government should educate and assist them in implementing the low-cost guerilla marketing activities. Since the study interestingly revealed that it is mostly females and students who are consuming fresh organic agricultural products, the latter should be chosen to be ambassadors of these products. Women councils and organisations as well as educational institutions should be involved in guerilla marketing to promote the benefits of fresh organic agricultural products. The guerrilla marketing weapons categorised by [13] like the New Media Weapons_-viral marketing and guerilla mobile can be considered in this new technological era whilst the Low Budget Weapons_clever ideas for small and medium enterprises can be an initial option for farmers. Yet, all guerilla marketing activities should be implemented after thoroughly considering its related ethical issues. The limitation of the study being the research methodology can be improved by: 1) using better probability techniques for sampling the respondents, 2) conducting further quantitative analysis by incorporating as well some hypotheses and 3) applying the grounded theory methods for better analysis of qualitative data. Future research can: 1) focus on specific demographic profiles to understand their point of views about the marketing of fresh organic agricultural products via guerilla marketing and 2) be done to evaluate profitability levels in terms of budgets and returns between the traditional and guerilla marketing activities.

\section{References}

[1] Vink, N. and Kirsten, J. (2002) Pricing Behaviour in the South African Food and Agricultural Sector. http://www.sarpn.org/documents/d0000327/P280_Pricing.pdf

[2] Vaiknoras, K., Norton, G. and Alwang, J. (2015) Farmer Preferences for Attributes of Conservation Agriculture in Uganda. African Journal of Agricultural and Resource Economics, 10, 158-173.

[3] Food and Agricultural Organisation of the United Nations (2015) Organic Agriculture. http://www.fao.org/organicag/oa-faq/oa-faq6/en/

[4] Wimberley, R.C., Vander Mey, B.J., Wells, B.L., Ejimaker, G.D., Bailey, C. and Burmeister, L.L. (2003) Food from Our Changing World: The Globalization of Food and How Americans Feel about It. http://sasw.chass.ncsu.edu/globalfood/foodglobal.html 
[5] Kohls, R.L. and Uhl, J.N. (1985) In Marketing of Agricultural Products. Macmillan Publishing Company, United States of America.

[6] Canan, A., Pinar, A. and Sinan, N. (2010) Guerrilla Marketing Communication Tools and Ethical Problems in Guerilla Advertising. American Journal of Economics and Business Administration, 2, 280-286. http://dx.doi.org/10.3844/ajebasp.2010.280.286

[7] Ives, N. (2004) Guerilla Campaign Are Going to Extremes, but Will Message Stick? New York Times, 24 June, 23.

[8] Faten, F. (2012) The Role of Guerilla Marketing Strategy to Enrich the Aesthetic and. International Design Journal, 2, 111-119.

[9] Patalas, T. (2006) In Guerilla-Marketing: Secrets for Making Big Profits from Your Small Business. Houghton Mifflin, Boston.

[10] Fadiga M.L. and Makokha, S. (2014) Consumer Valuations of the Quality and Safety Attributes of Milk and Meat in Kenya. African Journal of Agricultural and Resource Economics, 9, 91-105.

[11] Nufer, G. (2013) Guerilla Marketing-Innovative or Parasitic Marketing. Innovative Marketing, 9, 60-68.

[12] Alena, K. (2012) Guerilla Marketing New Concept in Practice Sport Master Case. Thesis (Bachelor), Mikkeli University of Applied Sciences, Mikkeli.

[13] Drüing, A. and Fahrenholz, K. (2008) Guerrilla Marketing. Thesis (Bachelor of Business Administration Degree), Saxion University, Enschede.

[14] Luxton, S. and Drummond, L. (2000) What Is This Thing Called “Ambient Advertising”? Proceedings of the ANZMAC (Australian \& New Zealand Marketing Academy Conference) 2000, Visionary Marketing for the 21st Century: Facing the Challenge, Gold Coast, 28 November-1 December 2000, 734-738.

[15] Hutter, K. and Hoffmann, S. (2011) Guerrilla Marketing: The Nature of the Concept and Propositions for Further Research. Asian Journal of Marketing, 5, 39-54. http://dx.doi.org/10.3923/ajm.2011.39.54

[16] Meenaghan, T. (1994) Point of View: Ambush Marketing-Immoral or Imaginative Practice? Journal of Advertising Research, 34, 77-88.

[17] Cruz, D. and Fill, C. (2008) Evaluating Viral Marketing: Isolating the Key Criteria. Emerald Insight, Marketing Intelligence and Planning, 26, 743-758. http://dx.doi.org/10.1108/02634500810916690

[18] Bjerke, B. and Hultman, C.M. (2002) Entrepreneurial Marketing: The Growth of Small Firms in the New Economic Era. Edward Wdgar Publishing Ltd., Cheltenham.

[19] Lawrence, F. and Adeniyi, A. (2013) Guerrilla Marketing: A Sustainable Tool for Entrepreneurs and Marketing Practitioners. Journal of Science and Science Education, 4, 44-54.

[20] Baltes, G. and Leibing, I. (2008) Guerrilla Marketing for Information Services? New Library World, 109, 46-55. http://dx.doi.org/10.1108/03074800810845994

[21] Barry, T.E. and Howard, D.J. (1990) A Review and Critique of the Hierarchy of Effects in Advertising. International Journal of Advertising, 9, 121-135.

[22] Ghirvu, A.I. (2013) The AIDA Model for Advergames. The USV Annals of Economics and Public Administration, 13, 90-98.

[23] New Agriculturist (2015) Country Profile-Mauritius. http://www.new-ag.info/en/country/profile.php?a=2811

[24] (2007) Report on Strategic Options in Crop Diversification and Livestock Sector 2007-2015. http://www.areu.mu/files/pub/areunssp.pdf

[25] Juwaheer, T.D. (2005) Emerging Shades of Green Marketing Conscience among the Population of a Small Island Economy-A Case Study of Mauritius. http://irfd.org/events/wfsids/policypapers/policy_tjuwaheer.pdf

[26] Rawal, P. (2013) AIDA Marketing Communication Model: Stimulating a Purchase Decision in the Minds of the Consumers through a Linear Progression of Steps. IRC's International Journal of Multidisciplinary Research in Social \& Management, 1, 37-44.

[27] Li, J. and Yu, H. (2013) An Innovative Marketing Model Based on AIDA: A Case from E-Bank Campus-Marketing by China Construction Bank. iBusiness, 5, 47-51. http://dx.doi.org/10.4236/ib.2013.53B010

[28] Blair, T.C. and Chiou, S.C. (2014) The Impact of Brand Knowledge on Consumers of Different Genders and from Different Cultures. Asia Pacific Management Review, 19, 47-59.

[29] Sawmy, T. and Damar-Ladkoo, A. (2015) Wholesale and Retail E-Commerce in Mauritius: Views of Customers and Employees. Studies in Business and Economics, 10, 170-186.

[30] Wu, Y.L. and Shang, S.S.C. (2013) Do Happier Customers Generate More Profits? An Analysis of Customer Contribution in a Bank. Asia Pacific Management Review, 18, 391-406. 